\title{
What makes men and women identify with Judith? A Jungian mythological perspective on the feminist value of Judith today
}

\author{
Author: \\ Helen Efthimiadis-Keith ${ }^{1}$ \\ Affiliation: \\ ${ }^{1}$ School of Religion, \\ Philosophy and Classics, \\ University of KwaZulu-Natal, \\ South Africa \\ Correspondence to: \\ Helen Efthimiadis-Keith \\ Email: \\ helenkeith@fnbconnect.co.za \\ Postal address: \\ Private Bag X01, Scottsville \\ 3209, South Africa \\ Dates: \\ Received: 28 May 2012 \\ Accepted: 14 June 2012 \\ Published: 23 Aug. 2012 \\ How to cite this article: \\ Efthimiadis-Keith, H., 2012, \\ 'What makes men and \\ women identify with Judith? \\ A Jungian mythological \\ perspective on the feminist \\ value of Judith today', \\ HTS Teologiese Studies/ \\ Theological Studies 68(1), \\ Art. \#1267, 9 pages. http:// \\ dx.doi.org/10.4102/hts \\ v68i1.1267
}

C 2012. The Authors. Licensee: AOSIS OpenJournals. This work is licensed under the Creative Commons Attribution License.
Inspired by her student's overwhelmingly positive interpretation of Judith as a model for women's liberation in diverse African contexts - despite the debate around the feminist value of Judith-Judith - the author deals with what could possibly allow men and women, particularly the latter, to interpret Judith positively today. Given her interest in Jungian individuation theory and Ancient Near Eastern (ANE) mythology, the author investigates the subject matter by exploring Judith's relation to male and female individuation patterns, the myths of the hero's quest and Demeter-Kore, and ANE warrior-goddess myths.

\section{Introduction}

\section{Personal gleanings from biblical scholarship and Judith/Judith}

Over the years, I have learned a number of things as a Christian feminist biblical scholar that will always stay with me:

- God cannot be manipulated

- there is no single way of interpreting any biblical passage or, for that matter, any situation in life

- being a biblical scholar is (or should be) a position of extreme humility: we simply cannot say anything about any text with absolute certainty.

My favourite Jewish apocryphal heroine, Judith, competently embodies these (and other) principles or understandings:

1. She is very clear about the fact that God cannot be manipulated. Rather than attempting to test God (Jdt 8:12-14) by 'binding' His will ${ }^{2}$ with a five-day ultimatum as the people and their leaders have done (Jdt 7:30-31; 8:9, 11), she conveys the understanding that God is completely free to do as He pleases in the current crisis: 'For if he does not choose to help us within these five days, he has power to protect us within any time he pleases, or even to destroy us in the presence of our enemies. Do not try to bind the purposes of the Lord our God; for God is not like man, to be threatened, nor like a human being, to be won over by pleading. Therefore, while we wait for his deliverance, let us call upon him to help us, and he will hear our voice, if it pleases him' (Jdt 8:15-17, [author's own emphasis]).

2. Apart from being able to interpret God differently, perhaps because of her extreme piety and constant fellowship with Him (see Jdt 8:4-6, 8), Judith alone understands that there is no single way of interpreting the current crisis. According to the Bethulians, their dire situation is clear evidence of God's punishment for their sin (Jdt 7:28), but according to Judith, this is not the case at all (Jdt 8:18-20). For her, this situation is one in which God is testing his people, and one in which they should remain true to him as an encouragement to the rest of the land (Jdt 8:25-27). Apart from offering a different and, to my mind, a more liberative interpretation of the current crisis, she alone is able to see beyond it. Giving in to the Assyrian aggressors may well solve the Bethulians' immediate water crisis, but it will also leave the whole of Judea vulnerable to Holofernes' ravages, bringing about the destruction of the temple and 'the desolation of all our inheritance' (Jdt 8:21-23). ${ }^{3}$ Clearly, Judith understands that interpretation influences action and has consequences beyond the immediate.

3. Two elements which we have encountered so far convey Judith's humility: her extreme piety and her radical conception of God's freedom - it takes humility to allow God to be God.

1.Judith refers to the Book of Judith, while Judith refers to the character by the same name.

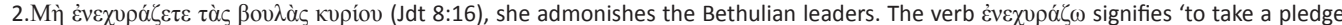
from one or to take in pledge', which is perhaps why the RAPC translates as follows: 'Do not try to bind the purposes of the Lord our God' (Efthimiadis-Keith 2004:216 fn. 32). C.A. Moore's (1985:177) 'do not impose conditions on the Lord our God' is, to my mind, a far better translation which takes account of the context of Judith's utterance and 'clearly brings out exactly what the Greek literally says: "do not take the will/counsels of our Lord God in pledge"' (see Efthimiadis-Keith 2004:216 fn. 32).

3.For an in-depth discussion of Judith's superior theological understanding of the situation and its import, please see Efthimiadis-Keith (2004:216-219). 
Judith's humility is also seen in the advice she provides: the people should continue praying whilst waiting for God's deliverance and continue thanking Him despite their circumstances (Jdt 8:17, 25-27). Her humility is further seen, amongst others, by the fact that she:

i. gives God the glory for her successes (Jdt 13:14-16; 16:1$17 ; 16: 17)$ - despite receiving the highest accolades from the Bethulian and Judean leadership (Jdt 13:18-20; 15:9-10) ${ }^{4}$ and being celebrated as a war hero (Jdt 15:12)

ii. returns home to a simple life-style (Jdt 16:21-22) once the great victory celebration is over (Jdt 15:12-13; 16:18, 19), despite receiving life-time honours from her people (Jdt 16:21, 22). ${ }^{5}$

\section{Interpreting Judith/Judith: Scholarly opinion and confusion}

Points (i) and (ii) above have become two of the central points - if not the central points - in the debate surrounding Judith's feminist suitability. ${ }^{6}$ For some feminist or profeminist ${ }^{7}$ biblical scholars, Judith's deliverance of her people is completely overshadowed by the insistence that God is the actual deliverer, not Judith. For others, the liberative aspects of Judith, such as her obvious superiority over all the men in the story, are further vitiated by the fact that she returns home after her great feat, she does not assume public office. For others yet, her use of deception and female sexuality in achieving her aims reinforces traditional patriarchal stereotypes about women, thus nullifying any positive value that she may have for women today:

despite its own thematics, the Book of Judith cannot afford to be feminist. It stresses that it is not Judith, but God, who has killed Holofernes - 'by the hand of a woman' (16:6). She was merely an instrument of the true patriarchal $[\mathrm{sic}]$ power ... (Stocker 1998:8-9)

Judith first had to liberate herself, using typical female weapons in order to be able to defeat the Assyrian army ... Even her rhetorical skills were used to deceive and murder another human being! (Cornelius 2009:250)

Unfortunately, Judith does not become a liberated woman at all or does not rise into a position of prominence ... In the end, she returns to the private sphere and is reinscripted into androcentric Israel ... She returns to a role where she is apart, ascetic and asocial ... [becoming] a model for the typical subordinate role of women in patriarchy! (Cornelius 2009:256)

A reading of the Latin literature which contains the conopeum motif serves to illuminate the meaning and function of the $\kappa \omega v \omega ́ \pi ı v$ in the story of Judith. The construction of gender roles in the Book of Judith does not in fact subvert these roles, but rather reinforces them in their patriarchal connotation. Ultimately, therefore, the story of Judith offers a truly patriarchal explanation for the scandalous fact that a woman, however God-fearing she may be is able to kill a man. (Schmitz 2010:80)

4.See also Achior's high praise for Judith in 14:7

5.Other actions that signify her humility include (1) setting her stewardess free (16:23), and (2) distributing her wealth to her relatives before she dies (16:24)

6.For a detailed analysis of this debate, see Efthimiadis-Keith (2010:91-111). This section is drawn largely from parts of this article.

7.'Pro-feminist' is P.J. Milne's term and refers to biblical scholars who do not necessarily subscribe to feminism or feminist biblical interpretation but who attempt 'to incorporate the results of feminist scholarship in their work' (Milne 1993:43).
[S] he is not a counter-cultural character, but remains very much a man's woman ... She repeatedly identifies with male models ... $[a n d]$... against female characters when she ignores the plight of Dinah $[s i c]$ and the Shechemite women ... In short ... Judith [is] the very antithesis of a woman-identified woman.

[She] effectively reinforces the patriarchal ideology that women are inferior and secondary by repeatedly making self-effacing ... statements. Not only does she attribute all her success to the deity ... but she makes a point of emphasizing the negative attitudes held by her Israelite or Jewish society toward women. In Jdt 9:9-10 she, not the narrator, draws attention to the added ignominy of being defeated by a woman ...

In short, Judith is presented, and as a narrative character, presents herself virtually completely from a male, patriarchal perspective ... [H]er very action is rooted in the dynamics of men's fear of women's sexuality...

Judith liberates neither herself nor her countrywomen from the status quo of the biblical gender ideology. (Milne 1993:54-55)

Despite their negative evaluations, the self-same critics - and others besides - also see positive elements in Judith: the myth of Judith is ... a radical and feminist alternative to the oedipal myth, and to all that it signifies about the ordering of Western culture (Stocker 1998:23).

\section{According to Cornelius (2009):}

The audience and reader ... cannot but be motivated by Judith's successes and persuaded to follow her pious life. One comes to think that this text might serve to persuade women that it is not only the male who can play an important role in God's peoples' lives - that women actually do have a role to play in a patriarchal world. (p. 249)

For ancient women, Judith's moving outside the limits of ancient patriarchy must have been a positive characteristic. (p. 251)

Schmitz (2010) writes:

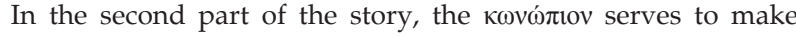
Holofernes appear as a far more effeminate, weakened figure than at the beginning, and opens up an interesting gender perspective in [his] portrayal ... as womanlike and having deficient masculinity. (p. 77)

It is the superiority of Judith over all the men in the story, and the inversion of gender roles, which led Nickelsburg to exclaim that Judith is 'especially striking for its feminism' [sicanachronistic] (Nickelsburg 1981:108). Similar considerations have led Jordaan to aver that 'the book Judith [sic] challenged the status quo in various areas. The most prominent area was to show, in contrast with Jesus Ben Sira, the worth of women' (Jordaan 2009:3). Likewise, Narito, who writes within the context of 'Valiant Phillipina Women', declares that the deeds and characterisation of Judith serve as 'a critique to the Hebrew patriarchal structure that blocked the independence and leadership of women' (Narito 1992:55). In fact, she criticises negative, androcentric interpretations of Judith and its heroine for failing to grasp 'the lesson the writer wishes to convey, which is that God wants people to be free from all forms of oppression and domination' (1992:54). For her (1992:57-58) the book clearly empowers powerless women to struggle against oppressive regimes and build societies of 'love, truth, justice, and peace.' 


\section{A Jungian psychoanalytic perspective on Judith/Judith}

When I began my studies on Judith almost two decades ago, I was just as annoyed with its negative, androcentric interpretations as Narito, and for similar reasons (although I would not have been as effusive about the societies she claims Judith encourages). I tried to make light of them, but my own discoveries kept on troubling me.

In my 2004 monograph, The enemy is within: A Jungian psychoanalytic approach to the book of Judith, I noted, amongst others, that Judith's descent to and return from Holofernes' camp matched exactly the structural components of the hero myth or hero's quest and its alternative, the night sea journey. From a psychoanalytic perspective, this myth is taken as an expression of the human individuation pattern but, as scholars such as Annis Pratt have shown, it is specific to men alone. Following Pratt's (1992:155, 162) contention that women's individuation patterns followed that of the Demeter-Kore myth (Bernstein 2004; Carlson n.d.; Tait 2010), and knowing that the biblical image of the cultic community is overwhelmingly feminine (Efthimiadis-Keith 2004:410), I was disturbed. Could it be that my Judith was actually a man in the form of a woman - nothing but another representation of the androcentric, male-identified ancient Israelite cultic community (2004:410)?

My analysis had also identified Judith as the anima of the Jewish nation (or faction thereof) that had produced the mythopoeic book (Efthimiadis-Keith 2004:18, 415, 420-421). ${ }^{8}$ Whilst the anima is a very powerful figure in Jungian psychoanalytic thought, the latter is not free of sexist concerns. For example, even though Jung regards the anima as the contra-sexual soul image that brings a male through to the final stage of the individuation process, namely the hieros gamos or the conscious merging of the opposites within him, he also equates her with Eros. Simultaneously, he equates the male contra-sexual image in women, the animus, with Logos:

The animus corresponds to the paternal Logos just as the anima corresponds to the maternal Eros ... I use Eros and Logos as conceptual aids to describe the fact that woman's consciousness is characterized more by the connective quality of Eros than by the discrimination and cognition associated with Logos. In men, Eros, the function of relationship is usually less developed than Logos. In women, on the other hand, Eros is an expression of their true nature, while their Logos is often a regrettable accident. It gives rise to misunderstandings and annoying interpretations in the family circle and among friends. This is because it consists of opinions instead of reflections, and by opinions I mean a priori assumptions that lay claim to absolute truth. (Jung 1959b:14-15, [author's own emphasis in the first three instances])

'This is a highly sexist and patriarchal image of woman, no matter how it is veiled in abstract, philosophical nomenclature' (Efthimiadis-Keith 2004:85; Pratt 1992:155). Moreover, did not the identification of Judith as anima further reinforce the male nature of the cultic community, thus excluding or at least marginalising women? Could the book be conveying the message that 'salvation is to be found [only] through the enactment of the male individuation cycle' (Efthimiadis-Keith 2004:410)?

On the other hand, as one of the most important archetypes of the collective unconscious, Judith-as-anima was free to be exactly who she was - sexy and chaste, pious, wise and deceptive, murderous and saintly, male and female ${ }^{9}$. To my mind, the book's depiction of Judith was therefore more true to human nature (after all who is totally 'good' or 'evil'?) and offered women the liberative potential of being all that they are without having to succumb to the patriarchal constraints of being either 'good' or 'bad', sexy or chaste, (stereotypically) male or female in their thinking, speech and behaviour. ${ }^{10}$

\section{What makes men and women identify with Judith's liberative deeds?}

Considering all the above, I came to rest about my favourite biblical book. However, I was still intrigued by what might enable such diverse, even oppositional readings of the book - apart from the binary categories created by the conscious mind (Efthimiadis-Keith 2010:93-94, 100). I was especially intrigued by what enabled men and women the latter in particular - to identify with this heroine and emulate her behaviour for the salvation of their people. ${ }^{11} \mathrm{My}$ fascination peaked when 70\% of my 2011 Honours Research Methodology class interpreted Judith as a heroine whose faith, determination and courage could be emulated in various ways to effect liberation for women within their particular African communities of faith. ${ }^{12}$ I was amazed not only by the students' overwhelmingly positive responses to the book, but also by the contexts to which they chose to apply Judith as a liberative model, such as: seeking leadership for women in particular churches or church denominations; empowering women in gogo-(granny)-headed households; encouraging women to take up political leadership (based on parallels between Judith and the first female leader of a political party in the South African province of KwaZulu-Natal); and standing up against the denigrating and oppressive (Kaunda 2011) rituals of sexual cleansing that widows must undergo amongst the Bemba people in Zambia.

These were very well thought-out, positive readings in very real current contexts - like that of Narito - not the rarefied stratosphere of academic discourse. What enabled these

9.According to Jung, archetypes possess the totality of all possible opposites, but the conscious mind is unable to cope with this fusion and consequently splits opposites into binaries such as good versus bad, sexual versus chaste, male versus female et cetera (see Jacoby 1992:62-65; Efthimiadis-Keith 2010:93).

10.Unfortunately, women have wittingly or unwittingly colluded with this binary view of their nature, which prevents them from being, enjoying and honouring the ful extent of themselves.

11.Stocker's (1998) brilliant monograph, Judith: Sexual Warrior. Women and Power in Western Culture, is full of such examples spanning the length and breadth of Judith's reception history, from the past to the present. See, for example pages 67-134, especially 111-123, which discuss Charlotte Corday's murder of the demagogue, Marat, during the Terror Phase of the French revolution in exact Judithic fashion!

12.In order to test their acquisition of research skills, I asked these students to pretend that they were writing a research project on the feminist value of Judith and to prepare a research proposal, which included a research-design and literature review, for their final examination. A total of 19 out of the 27 students $(70 \%)$ viewed Judith in a very positive light, while only $2(7 \%)$ regarded her in $(70 \%)$ viewed Judith in a very positive light, while only $2(7 \%)$ regarded her in
a negative light. Of the remainder, $6(22 \%)$ were ambivalent towards the book's feminist value, with 4 of these leaning towards the positive side. 
students and scholars such as Narito to interpret Judith in such positive, liberative ways? Being convinced that the book was as archetypal as its heroine, I began to wonder whether its archetypal nature allowed it to represent the male and female individuation cycles simultaneously. Or, was it possible that Judith invoked the age-old warrior-woman or goddess archetype, thus touching the inner recesses of people's (particularly women's?) souls at this time and calling out for its emulation?

In this article I deal with the issues raised in the previous paragraph, namely (1) Judith's relation to the myths of the hero's quest and Demeter-Kore and (2) Judith's relation to ANE warrior-woman or goddess myths in terms of the effect that they may have in drawing men and women in particular, at this time, to unlock the liberative potential which Judith/ Judith holds.

I begin, then, with a brief discussion of the importance of the hero's quest and the Demeter-Kore myths for the male and female individuation cycles as well as their relation to the book of Judith.

\section{The Hero's Quest and Demeter- Kore myths: Their significance in the male and female individuation cycles and their relation to Judith/Judith \\ The Hero's Quest}

According to Jung - the father of modern psychoanalysis - individuation 'is a (life-long) psychological process that drives a human being to become the "individual" - the unique, indivisible unit or "whole" person' (EfthimiadisKeith 2004:56) that she or he originally is (Jung 1940:3). As Monick (1991:34) has put it, the individuation journey is one that is 'deeply personal' while simultaneously being 'essentially mythic'. In other words, it exhibits personal peculiarities rooted in the individual's own conscious or unconscious psyche as well as common elements found in the collective psyche of humankind. For Jung, the myth of the hero's quest, more commonly known as the hero myth, is the clearest expression of the human urge towards individuation (Jung 1956:109-110).

Whilst there are many permutations of the male hero myth, for example, the myth of Hercules, the story of Moses and that of Jonah, two basic structural variants may be discerned, viz. the general and alternate patterns (Efthimiadis-Keith 2004:69-71). These will be outlined and discussed briefly below.

\section{The general pattern of the male Hero Myth}

a. A lack or imbalance sets the hero off on his quest for a solution to a foreign country or up a difficult mountain.

b. The hero arrives at his destination after passing many tests and/or overcoming numerous monsters. He is often accompanied by a shadowy companion, who seems to be his double, and offered advice by various deities and/or other magical creatures or people with magical powers (e.g. a magician, old woman or faithful animal).

c. Reaching his destination does not, however, entail the end of his problems, as the hero usually has to liberate a maiden and/or untold treasure from a dragon or other similar monster. (The hero is sometimes swallowed by the dragon he battles, but returns after slaying it from within, with the rest [a. and e.] following).

d. He liberates the maiden or treasure with the help of his magical friends, and returns to a hero's welcome in her and/or his own land.

e. The hero marries the maiden - usually as a reward for his bravery - and becomes a powerful leader who transforms his world and/or his vision of it.

\section{The alternate pattern male Hero Myth}

This pattern does not contain all the elements of the general pattern outlined above. Rather, it develops as an autonomous variant, based on the element of the hero being swallowed by the dragon or monster - the bracketed section in (c), above:

1. A hero is devoured by a water monster in the West.

2. The animal travels with him to the East, usually during the night.

3. Whilst in the monster's belly, the hero lights a fire and, feeling hungry, cuts himself a piece of the heart.

4. The endangered monster soon glides to land and the hero escapes by cutting the animal open from within and slipping out.

5. The hero's hair might have fallen out because of the intense heat in the monster's belly. Oftentimes, the hero simultaneously frees all those previously swallowed by the monster.

Despite the differences between these variants, the hero's battle with and overcoming of the dragon or sea or other monster(s) is crucial to both, as it represents his separation from his mother (Henderson 1964:126) and so his battle with his psychological contra-sexual female image, that is, his anima (Jung 1959a:13). ${ }^{13}$ The hero's marriage to the maiden then symbolises the crux of a male individuation cycle, namely the integration of the anima (Efthimiadis-Keith 2004:70). The latter, in turn, symbolises the resultant hieros gamos [holy marriage] or union of opposites (Jung 1940:28) the acme of individuation, which then leads a man to greater societal integration at a conscious level.

In some myths, (however, ) the hero is unsuccessful in his battle against the dragon (which) symbolises (his) identification with the collective unconscious, the maternal consciousness, and a failed cycle of individuation (Efthimiadis-Keith 2004:70).

\section{The relation between the Hero's Quest and Judith's journey to and from Holofernes' Camp}

As previously indicated, Judith's journey to and from Holofernes' camp parallels exactly the structural elements of the hero myth - in both its formats (Efthimiadis-Keith 2004:391-394). For the sake of brevity, however, I will tabulate the parallels between Judith's journey and the general pattern

13.Apart from being an element of the collective unconscious, a man's anima is formed primarily by or imbued primarily with his perceptions of his mother - his mother-imago (cf. Jung 1959a:13). 
of the hero's quest, ${ }^{14}$ referring the reader to my book for parallels with the night sea journey (2004:394) see Table 1.

As can be seen from the Table above, there are only two real differences between Judith and the male hero myth: Judith is female whereas the hero of the hero's quest is male, and Judith remains unmarried, or arguably resists human suitors in favour of YHWH. Judith's journey otherwise parallels the structural pattern of the hero's quest exactly. This is not the case with the Demeter-Kore myth, to which I now turn.

\section{The Demeter-Kore myth}

According to various analysts and commentators (see e.g. Bernstein 2004; Carlson n.d.; Tait 2010; Pratt 1992), women's individuation patterns seem to be structured after the Demeter-Kore myth. The correlation between the DemeterKore myth and women's individuation is hardly surprising, as this myth represents three archetypes which are crucial to women's development, namely the Mother (Demeter), the Maiden (Kore or Persephone), and the Crone (Hecate) (Carlson n.d.). However, as I hope to show, this may not be as naturally definitive of women's individuation as some scholars think.

The 'most complete and well-known source' (Carlson n.d.) of this myth is found in the First Homeric Hymn to Demeter. ${ }^{15}$ It may briefly be summarised as follows:

14.This table is adopted and adapted from Efthimiadis-Keith (2004:392-393).

15.'The Homeric Hymns are a collection of thirty-three Greek poems ... [ranging] in length from 3 to 500 lines... The largest four are complete epic narrative poems in themselves' af C7th - C th BC. A few of the shorter pems are clerly C7 Ares was Probably not composed till Roman times' (Homeric Hyns, $1-3, n^{\prime}$.). . There are two Homeric hymns to Demeter. The first is a complete narrative in itself (Homeric Hymns, 1-3, n.d.), whilst the second one is very short. I begin to sing of rich-haired Demeter, awful goddess, of her and of her daughter lovely Persephone. Hail, goddess! Keep this city safe, and govern my song' (Homeric Hymns 5-33, n.d. [author's capitalisation]). For an excellent translation of Homer's first Hymn to Demeter with relevant commentary, see Gregory Nagy's translation, Homeric Hymn to Demeter, n.d.).
Hades, god of death and the underworld, emerges from below the earth in his fiery chariot and abducts Persephone, the young daughter of Demeter and Zeus, dragging her, kicking and screaming down to his kingdom to be his bride. When Demeter, goddess of fertility, finally hears her daughter's voice she descends speedily from Olympus and frantically searches for her. However, neither god, nor mortal, nor bird (messengers of truth) will help her in her quest. Not once does she eat, drink or bathe as her grief for her lost daughter consumes her. (n.p.)

On the tenth day of her quest, Hecate approaches and relates how she had heard Persephone's cries, but did not see her abductor. Silently, the two goddesses proceed to Helios, whom Demeter implores to reveal the identity of Persephone's abductor. Out of respect for her (Demeter), Helios reveals that Zeus himself gave Persephone to Hades as wife. Helios' attempts to assuage Demeter's grief are to no effect. (It's not so bad to have Hades as a son-in-law, he says, urging Demeter to cease from her anger). The goddess descends into an even more terrible grief than before, deepened by her anger with Zeus.

Shunning Olympus, she chooses instead to visit human cities. She arrives at Eleusis disguised as the old and childless childminder, Doso. The king's daughters entreat their mother, Metaneira, to employ her as a nursemaid for their newborn, much-awaited and much-desired brother, Demophoon.

All goes well and the young son thrives in Demeter's (Doso's) hands - without food - until his mother sees Demeter holding him into a fire - to burn off his mortal parts. Demeter reacts to Metaneira's shrieks of terror with severe anger. Chastising her for her mortal foolishness, and revealing herself as the goddess, Demeter instructs the terror-stricken royal couple to build her a temple where she will inaugurate her mysteries.

TABLE 1: Parallels between the general pattern of the hero myth and Judith.

General pattern of the hero myth

A. A lack/imbalance sets the hero off on his quest for a solution to a foreign country or up a difficult mountain

B. The hero arrives at his destination after passing many tests and/or overcoming numerous monsters - often accompanied by a shadowy companion and other magical helpers (e.g. gods, old women, or an animal friend).

C. Reaching his destination does not, however, entail the end of the hero's problems, as he usually has to liberate a maiden and/or untold treasure from a dragon or other similar monster.

D. He liberates the maiden/treasure with the help of his magical friends, and returns to a hero's welcome in her and/or his own land.

E. The hero marries the maiden - usually as a reward for his bravery - and becomes a powerful leader who transforms his world and/or his vision of it.

F. Alternatively, he is sometimes swallowed by the dragon he battles, but returns after slaying it from within, with the rest ( $D$ and $E$ ) following.
Judith

The attacking Assyrians block off Bethuliah's water spring, causing great thirst and panic to set in. Judith voluntarily sets off down the mountain to the enemy camp in order to rectify the situation (Jdt 7:1-10:10).

Judith descends to the foothills of Bethuliah and gains access to Holofernes' tent. In doing so, she passes seven tests:

1. she bluffs the patrol into thinking she has come to assist Holofernes

2. the soldiers all desire her but no one harms her

3. she fools Holofernes and his entire entourage as to the nature of her 'mission'

4. Holofernes grants her safe passage in and out the camp 'to wash herself'

5. she resists the offer to eat non-kosher food

6 . she escapes Holofernes' intended seduction

7. she escapes undetected after having slain Holofernes (Jdt 10:10-13:10)

Judith is accompanied by her faithful stewardess, and is seemingly offered advice by YHWH, which is the assumption underlying her prayers and resultant actions (see Jdt 9:2-14; 12:5; 13:7). The kosher food (Jdt 10:5; 12:1-4), the food basket (Jdt 13:10, 15), and her nightly wash at the spring (Jdt 12:7) 'may be seen as demythologised magical elements which help her sustain her presence of mind etc. whilst she is in the enemy camp' (Efthimiadis-Keith 2004:392).

Having arrived at the camp, Judith must make sure that she is not violated, and that her deception and Holofernes' murder remain undetected. She liberates Holofernes of priceless treasure, his head, as well as his bed canopy (cf. especially Jdt 12:10-13:10).

Judith is assisted by her stewardess throughout and returns to a hero's welcome in Bethuliah (Jdt 10:5-6; 12:15, 19; 13:3, 9-10): she receives the highest praise from the leaders of her (Jd tocis and the women perform a victory dance to her honour with the men following. Judith society, and the with (Jdt 13:11-16:18).

The people's 3-month feast in Jerusalem (Jdt 16:20) possibly represents their re-marriage (return) to $\mathrm{YHWH}$.

However, Judith remains unmarried despite many suitors (Jdt 16:22), indicating that YHWH is her true husband. She becomes a powerful leader who leads her people to military victory, and her fame keeps her people safe for many years after her death. She transforms 'her society... her people's self-understanding, and their understanding of YHWH's nature and His role in their suffering' (Efthimiadis-Keith 2004:393, [author's own emphasis]).

Judith is NOT swallowed by 'the dragon', but slays Holofernes in his own tent, upon his own bed, with his own sword and returns to Bethuliah (cf. Jdt 8:32-34, 9:9; 10:10-13:10). 
This is done and Demeter retires to her temple where she sinks into further grief and depression over her lost daughter.

As a result of her grief and pain, Demeter causes famine and drought to spread over all the earth. Zeus, who had colluded with Gaia and Hades in his daughter's abduction, sends her numerous offers via other gods to entreat her to put an end to the catastrophe. Implacable, Demeter swears that she will never again set foot on Olympus unless she sees her daughter's beautiful face. Hearing this, Zeus relents and sends Hermes to persuade Hades to return Persephone to her mother. Persephone, who has been pining away for her mother, is overjoyed. Unfortunately, she has unwittingly eaten a pomegranate seed which Hades slipped her, thus ensuring her return to the underworld.

Hades returns Persephone to a joyous reunion with her mother. The reunion is marred when Demeter realises that her daughter had eaten some seed while in Hades, meaning that she (Persephone) would have to spend one season each year with Hades and the remaining three with her - as per agreement between herself (Demeter) and Zeus.

While on one level this myth is an ancient explanation for the origin of the seasons and the inauguration of the Elysian Mysteries, on another it is a highly significant portrayal of a part of the female individuation cycle as it aptly illustrates the complexities of the mother-daughter relationship (see Bernstein 2004) and a woman's need to integrate her female introjects (the Mother, Daughter and Crone) in her agon of individuation (Carlson n.d.). The latter represents one of the greatest differences between male and female individuation cycles.

Classical psychoanalytic theory has assumed that successful female individuation or development is structured after the male pattern reflected in the Oedipus myth. In other words, it has been believed that a woman's development depends on her separating from her mother and attaching herself to her father (Bernstein 2004:601). Newer theories, however, 'depict development as interactive and relational throughout the life cycle - leading not to separation but to autonomy with connectedness' (2004:601) as depicted in the Demeter-Kore myth. This myth aptly portrays 'the conflicts integral to the girl's triangular situation' (mother-self-father) and the highly ambivalent mother-daughter relationship (2004:601). It also reveals that development is not linear:

Once we recognize that the course of development is not linear, we should expect to see the woman revisiting, re-examining and re-synthesizing representations of self-versus-mother and self with-mother over her lifetime. (Bernstein 2004:601)

Thus, it is necessary that a woman does not separate completely from her mother, as a man (supposedly) has to do. Rather, she is to obtain autonomy within connectedness.

Moreover, Pratt (1992:153-156) is correct when stating that Jung and staunch Jungian psychoanalysts (Von Franz 1964:194) merely assumed that a woman's animus plays the same role in her individuation cycle as the anima plays in that of a man. She (Pratt 1992:159-160) demonstrates that, in modern women's individuation literature, the woman does not encounter a dual god or powerful male figure at the nadir of her individuation cycle that functions in the same way that the anima does for men. Rather, the male figure or 'horrible husband' whom the woman often encounters, 'stops her dead in her tracks ... dragging her into masochistic compliance with social standards' (Pratt 1992:161). Instead of being reborn, 'the female character falls into madness, determines to commit suicide, or lapses into a zombie-like state that precludes further development' (Pratt 1992:161). Pratt further observes that similar results occur when women encounter 'erotic, godlike figures' as they are 'often natural, antisocial, and above all anti-marital' (Pratt 1992:160-161). This justifiably suggests to her that these male figures represent not the animus but the shadow, which for women is 'socially conformist [vs. the antisocial aspects of the male shadow], incorporating women's self-loathing for their deviations from social norms, specifically the [patriarchal] norms of femininity' (Pratt 1992:161).

In conjunction with the above, Pratt also discovered that women's successful quests were facilitated by 'a powerful integrative mother-figure' (Pratt 1992:163). These mother figures are encountered at the nadir of women's quests, even as the dual mother or anima is encountered at the nadir of men's quests; they assist women to overcome their 'horrible husband' shadows and achieve 'a deeper and more holistic sense of the feminine' (Pratt 1992:162). Even so, this results in a woman's estrangement from society, as opposed to the integration, which causes the male to be welcomed back into society as a hero.

Considering the parallels between her discoveries and the Demeter-Kore myth, Pratt avers that the female individuation journey is structured after the archetypal pattern of this myth rather than that of the hero's quest (Pratt 1992:159). Indeed, comparing the basic outline of the Demeter-Kore myth ${ }^{16}$ with the structural elements of the hero's quest (Table 2) shows that there are immense differences between them, even as the differences between the male and female psyche - a factor which Jung also recognised later in his career (cf. Jung 1956:207)

The table above shows that there are immense differences between the hero myth and that of Demeter-Kore. In fact, there are only two direct similarities: the original quest (row A) and Hecate accompanying Demeter to Helios (row B). The latter, of course, is only a partial similarity as it does not cover the entire element denoted by row $B$.

\section{To summarise:}

- Men and women's psyches are different: for healthy individuation to occur, a woman needs to develop autonomy vis-à-vis her mother without losing her connectedness with her, whilst a man needs (psychological) separation from his mother and identification with his father.

16.Given that Demeter is the obvious protagonist of this myth, the outline will be constructed from her perspective rather than that of Persephone. 
TABLE 2: A comparison of the general pattern of the hero myth and that of Demeter-Kore.

\begin{tabular}{|c|c|c|c|}
\hline \multirow{2}{*}{\multicolumn{2}{|c|}{ General pattern of the hero's quest }} & \multicolumn{2}{|r|}{ Outline of Demeter-Kore myth } \\
\hline & & \multirow{2}{*}{$\begin{array}{l}\text { Similarities } \\
\text { - Demeter hears her daughter's voice and } \\
\text { descends to earth from Olympus to find } \\
\text { her. }\end{array}$} & \multirow[t]{2}{*}{ Differences } \\
\hline A. & $\begin{array}{l}\text { A lack/imbalance sets the hero off on his quest } \\
\text { for a solution to a foreign country or up a } \\
\text { difficult mountain. }\end{array}$ & & \\
\hline B. & $\begin{array}{l}\text { The hero arrives after passing many tests and/or } \\
\text { overcoming numerous monsters - often } \\
\text { accompanied by a shadowy companion and other } \\
\text { magical helpers (e.g. gods, old women, or an } \\
\text { animal friend). }\end{array}$ & $\begin{array}{l}\text { - Hecate tells Demeter what she had heard } \\
\text { and accompanies her to Helios to find out } \\
\text { who had abducted Persephone. }\end{array}$ & $\begin{array}{l}\text { - No one will initially help Demeter. } \\
\text { - She sinks into grief and depression. } \\
\text { - Earth is NOT her final destination, neither is meeting Helios. } \\
\text { - Helios tells Demeter the truth but urges her to cease from anger, as it is } \\
\text { not so bad to have Hades as her son-in-law, i.e. he tries to abrogate her } \\
\text { quest but does not actually attempt to stop her. } \\
\text { - Demeter does not have to pass through any tests. }\end{array}$ \\
\hline C. & $\begin{array}{l}\text { Reaching his destination does not, however, entail } \\
\text { the end of the hero's problems, as he usually has } \\
\text { to liberate a maiden and/or untold treasure from a } \\
\text { dragon or other similar monster. }\end{array}$ & & $\begin{array}{l}\text { - Neither earth nor Helios' domain is her destination. } \\
\text { - Having discovered that her daughter is in Hades, she does not attempt } \\
\text { to go there and rescue her. } \\
\text { - She does not battle anyone or anything. } \\
\text { - She is unable to liberate Persephone at this point. In fact, she is } \\
\text { encouraged/warned not to (attempt to) do so and 'obeys'. }\end{array}$ \\
\hline D. & $\begin{array}{l}\text { He liberates the maiden/treasure with the help of } \\
\text { his magical friends, and returns to a hero's } \\
\text { welcome in her and/or his own land }\end{array}$ & & $\begin{array}{l}\text { - There is neither liberation for the maiden nor a hero's welcome for } \\
\text { Demeter. } \\
\text { - Her depression worsens and she transforms herself into an old, childless } \\
\text { woman. } \\
\text { - Her attempts to immortalise (= liberate?) Demophoon are thwarted. } \\
\text { - At the end of her tale she is neither in her own land (Olympus) nor that } \\
\text { of the maiden (Hades). Rather, she hovers in the no-man's-land that } \\
\text { earth has become for her. }\end{array}$ \\
\hline E. & $\begin{array}{l}\text { The hero marries the maiden - usually as a reward } \\
\text { for his bravery - and becomes a powerful leader } \\
\text { who transforms his world and/or his vision of it. }\end{array}$ & & $\begin{array}{l}\text { - Demeter's attempts to fulfil her 'quest' are not rewarded - by either god } \\
\text { or man. } \\
\text { - She retreats to her newly-built temple on earth in even greater } \\
\text { depression. } \\
\text { - Her quest is partially rewarded by Zeus (he sends Hermes to persuade } \\
\text { Hades) only after she brings about large-scale destruction on earth } \\
\text { (and only because the gods were not getting their offerings as a result) } \\
\text { - Persephone is only allowed to come back to her mother for } 3 / 4 \text { of the } \\
\text { year. }\end{array}$ \\
\hline F. & $\begin{array}{l}\text { Alternatively, he is sometimes swallowed by the } \\
\text { dragon he battles, but returns after slaying it from } \\
\text { within, with the rest ( } D \text { and } E \text { ) following. }\end{array}$ & $\begin{array}{l}\text { - Demeter's depression deepens at } \\
\text { each step. Could this be an element of } \\
\text { swallowing? }\end{array}$ & $\begin{array}{l}\text { - Demeter never seems to come out of her depression in Homer's } \\
\text { rendition of this myth. }\end{array}$ \\
\hline
\end{tabular}

- The soul image in both men and women is female, and both genders require an anima-type figure to lead them to successful individuation.

- The myth which best represents a woman's complex psychological relation to her mother is that of DemeterKore, while the hero's quest - specifically the Oedipus myth - best illustrates a man's psychological need to separate from his mother.

Up to this point, I am in agreement with the theorists whose work has been discussed and I rejoice that integrating the feminine is the sine qua non of both male and female individuation cycles. However, contrary to Pratt, I no longer believe that the Demeter-Kore myth represents the totality of a woman's individuation experience. Retrospectively, I see that this insight is openly concealed in two of Pratt's discoveries that have deliberately been excluded from the preceding summary for discussion here:

- the male figures encountered in modern women's individuation cycles are representative of their shadows rather than their imaginary contra-sexual soul images

- these figures lead a woman to madness; overcoming them results in various forms of societal alienation.

To my mind, these points are reflective of the damage caused by patriarchal prescriptions for, fears of, and machinations against women, making it impossible for the Demeter-Kore myth to represent the totality of a woman's individuation cycle.

Considered rationally, the Demeter-Kore myth does not proffer any hope of positive individuation for women at all: they are either doomed to return to their 'horrible husbands'
- merge with their shadows, or they are doomed to wander the earth, away from their own kind (Demeter is a goddess), in desperation and depression, dependent on men, and constantly waiting for the sought-for-subject (Demeter). This is certainly not a depiction of a positive, successful individuation (even though it may be a part of that journey). It does not offer women any hope for empowerment, development, self-realisation, connectedness with others, victory over self, and other things which are meant to accompany psychological maturation or individuation. There is nothing liberative for women here.

Itself a patriarchal emendation of a woman-friendly 'original' (Carlson n.d.), the current Homeric Hymn to Demeter only reaffirms patriarchal stereotypes of women: weak, pathetic, emotional, unable to stand up to men, powerless and hopeless, reactive rather than proactive, always waiting, dependent on men - which is how patriarchal powers portray and want women to be. No, there is nothing developmental, empowering or liberative here. If we are looking for an empowering mythical model for women's liberation and individuation, then we need to seek for it elsewhere.

Moreover, when considered alongside the exact correlation between the hero myth and Judith (Table 1), the tremendous differences between the hero myth and Demeter-Kore (Table 2) show that it is impossible for there to be any direct and complete parallels between Judith and Demeter-Kore. In fact, the only correlations which I can see are the fact that both protagonists are female, both are accompanied by another female for all or part of their journey, and both descend (from Olympus or Bethuliah) in order to begin their quests. 
These correlations are minimal, vitiated by the fact that Demeter, unlike Judith, is what I would call a counterhero(ine), not a heroine: for one thing, she does not take charge of the situation in any way. She never engages those who conspired to bring about Persephone's abduction - her own 'horrible husband', Zeus, the earth goddess or mother, Gaia, and the ultimate 'horrible husband', Hades. Rather, she lashes out at those who had nothing to do with it, such as Metaneira and the people of the earth. Indeed, she seems beset by a low self-esteem and a belief in her own helplessness (despite being a goddess!) which robs her of her ability to be active and, more importantly, proactive in 'saving the maiden' or sought-for-person. As such, she may be classed as a counter-hero.

Be that as it may, considering Judith's identification with the male individuation cycle and its lack of identification with that of the female as represented partially by the DemeterKore myth, the reader may be justified in thinking that the book is wholly male-identified, despite its obviously female heroine. After all, its deep structure is male-identified, despite a strong feminine presence in its surface structure ${ }^{17}$. But all is not as it seems ...

\section{Judith/Judith and the ANE warrior/ trickster goddesses, Anat-Astarte}

Within Judith's primal mythological context, the ANE, we find various myths of powerful warrior-goddesses, such as Inanna or Ishtar, Anat-Astarte, and Sekhmet, amongst others. Spatial constraints prevent me from discussing Judith's relation to all of these goddesses. I will therefore focus on the parallels between the myths of Anat-Astarte and Judith. This comparison is particularly instructive, as Judith is clearly patterned after Deborah-Jael who, in turn, is clearly patterned after Anat-Astarte, the warrior-goddess and lover of Baal. For example, the three sets of ladies share the following characteristics; amongst others: ${ }^{18}$

- they are female warriors fighting on behalf of and out of love for or devotion to a male god (YHWH or Baal)

- each has a male lackey: Barak, Yatpan, the Bethulian leadership (or maybe Achior?)

- they are set on and successful in the complete destruction of YHWH's/Baal's enemies

- they freely employ deceit and female sexuality in their warring

- their warring has a transformative effect

- Jael, Judith and Astarte are known as 'crushers of the skull' within the context of a 'challenge of dominion' (Taylor 1982:101-102).

The links between Judith, Deborah-Jael the prophetess and judge of Israel, and the powerful warrior goddess Anat-

17.See further Efthimiadis-Keith (2004:317-321): Achior is Judith's effective protagonist, that is the main protagonist from a psychological point of view. This
concept is drawn from Dawson's (1997:257) astute observation that the overt concept is drawn from Dawson's (1997:257) astute observation that the overt hero or protagonist of a particular story may not necessarily be the same as it psychological protagonist. While the former is readily seen in a story's surface structure, the effective protagonist may be discerned by probing the story's
deeper, psychological structure.

18.These and other correlations are discussed in detail in Efthimiadis-Keith (2011), from which parts of this section have been adopted and adapted.
Astarte are strong indeed. In all likelihood, they are also (consciously and/or unconsciously) intentional given the Northern origin of the Deborah-Jael story: it is possible, for example, that Northern Israelites took the story of DeborahJael to Egypt where it was transformed into that of Judith to encourage the suffering Jewish communities at Elephantine and Leontopolis (see Bruns 1954:12-13; Efthimiadis-Keith 2011:301). The links between Judith, Deborah-Jael and AnatAstarte are further strengthened by (inter alia):

- the polylatrous nature of the Northern Israelite community, which included the worship of Anat/Asherah/Astarte alongside that of YHWH (see Van der Toorn 1998:13-23)

- the worship of Anat-Yahu at Elephantine (Van der Toorn 1992:80-81)

- the parallels between events occurring at Elephantine and Leontopolis and those reflected in Judith (EfthimiadisKeith 2011:311-317)

- the fact that Leontopolis is known as 'the mound of the Jewess', with Judith meaning 'Jewess' (2011:319).

The above, as I have argued elsewhere (Efthimiadis-Keith 2011:320), make it possible to see Judith as an embodiment of Anat-Yahu which, in turn makes, her an embodiment of the archetypal feminine. This surely indicates that Judith is also female-identified on the level of its deep structure!

One might, therefore, argue that the book is both male- and female-identified at a deep-structure level. In other words, Judith/Judith is depicting the full range of opposites inherent to any archetype, including good-bad, peace-war, lovehate, sexuality-virginity, and male-female. The book itself is thus archetypal (or archetypally structured) and defies the binarism with which it is often approached. As such, it transcends gender boundaries in the true sense of the word.

I would like to suggest that it is this deep-level, transcendence of gender boundaries that has called upon men and women to claim Judith as a model of liberation for their own people. Not least of these has been my 2011 cohort of Research Methodology Honours students whose work I discussed earlier. My students' responses show that Judith's femaleidentification is very strong despite its patriarchal leanings.

\section{Conclusion}

This article has investigated the feminist value of Judith at the hand of male and female individuation cycles, the relationship between Judith and Anat-Astarte and the way that men and women have entered into the Judithic drama to effect liberation for their people. It has shown that Judith/ Judith is both female- and male-identified vis-à-vis Judith's relation to Anat-Astarte or the archetypal feminine and the parallels between Judith and the male individuation cycle. This, for me, shows the true genius of this book: as an archetypal communication of the unconscious psyche it transcends gender boundaries - it is both andro- and gynocentric - and vitiates the binarism inherent to androcentric readings of Judith and its heroine. 


\section{Acknowledgements Competing interests}

The author declares that she has no financial or personal relationship(s) which may have inappropriately influenced her in writing this article.

\section{References}

Bernstein, P.P., 2004, 'Mothers and daughters from today's psychoanalytic perspective', Psychoanalytic Inquiry 24(5), 601-628. http://dx.doi. org/10.1080/07351692409349106

Bruns, J.E., 1954, 'Judith or Jael?', Catholic Biblical Quarterly 16, 12-14.

Carlson, K., n.d., 'Like wheat that springeth green: Death and return in the myth of Demeter and Persephone', viewed 30 June 2011, from http://www.endicottstudio.com/rdrm/rrpersephone.html

Cornelius, E.M., 2009, 'An interpretation of the rhetorical power of the dual power of the character of Judith', Theologia Viatorum: Journal for Theology and Religion in Africa 33(3), 242-260.

Dawson, T., 1997, 'Jung, literature, and literary criticism', in P. Young-Eisendrath \& T. Dawson (eds.), The Cambridge companion to Jung, pp. 255-280, Cambridge University Press, Cambridge. http://dx.doi.org/10.1017/CCOL0521473098.014

Efthimiadis-Keith, H., 2004, The enemy is within: A Jungian psychoanalytic approach to the book of Judith, Brill, Boston. (Biblical interpretation series 67).

Efthimiadis-Keith, H., 2010, 'Judith, feminist ethics and feminist biblical/Old Testament interpretation', Journal of Theology for Southern Africa 138, 91-111.

Efthimiadis-Keith, H., 2011, 'On the Egyptian origin of Judith, or Judith as Anat-Yahu', Journal for Semitics 20(1), 300-322.

Henderson, J.L., 1964, 'Ancient myths and modern man', in C.G. Jung \& M-L. von Franz (eds.), Man and his symbols, pp. 104-157, Aldus Books, London.

Homeric Hymns, 5-33, n.d., viewed 09 November 2011, from http://www.theoi.com/ Text/HomericHymns3.html\#13

Homeric Hymns 1-3, n.d., viewed 09 November 2011, from http://www.theoi.com/ Text/HomericHymns1.html

Homeric Hymn to Demeter, n.d., transl. G. Nagy, http://www.uh.edu/ cldue/ texts/ demeter.html, first viewed 30 June 2011, from http://www.uh.edu/ cldue/texts/ demeter.html\#_ftnref2, current Internet reference viewed 09 November 2011.

Jacoby, M., 1992, 'The analytical psychology of C.G. Jung and the problem of literary evaluation', in R.P. Sugg (ed.), Jungian literary criticism, pp. 59-74, Northwestern University Press, Evanston.

Jordaan, P.J., 2009, 'The pendulum is never static: Jesus Sira to Jesus Christ on women in the light of Judith, Susanna and LXX Esther', HTS Teologiese Studies/Theological Studies 65(1), 1-6.
Jung, C.G., 1940, The integration of the personality, transl. S. Dell, Routledge \& Kegan Paul, London.

Jung, C.G., 1956, Two essays on analytical psychology, transl. R.F.C. Hull, Meridian Books, New York.

Jung, C.G., 1959a, Aion: Researches into the phenomenology of the self, 2nd edn., transl. R.F.C. Hull, Routledge \& Kegan Paul, London. (The collected works of C.G. Jung, 9:2)

Jung, C.G., 1959b, The archetypes and the collective unconscious, 2nd edn., transl. R.F.C. Hull, Routledge \& Kegan Paul, London. ( The collected works of C.G. Jung, 9:1).

Kaunda, M.M., 2011, 'The concept of widow sexual cleansing among the Bemba people in Zambia: A postcolonial reading of Judith', paper presented as part of the June 2011 examinations in the Research Methodology course (RELG701), at the University of KwaZulu-Natal, Pietermaritzburg.

Milne, P.J., 1993, “'What shall we do with Judith?": A feminist reassessment of a biblical "heroine"' Semeia 62, 37-58.

Monick, E., 1991, Castration and male rage: The phallic wound, Inner City Books, Toronto.

Moore, C.A., 1985, Judith: A new translation with introduction and commentary, Doubleday, Garden City.

Narito, Z.C., 1992, 'The book of Judith', in O.C. Lee, M.J. Choi, S.A. Lee-Park, E. Kim, M. Rodriguez \& D. Goodsir (eds.), Women of courage: Asian women reading the Bible, Asian Women's Resource Centre for Culture and Theology, pp. 53-62, SaDang Publishing House, Seoul.

Nickelsburg, G.W.E., 1981, Jewish literature between the Bible and the Mishnah: A historical and literary introduction, SCM Press, London.

Pratt, A.V., 1992, 'Spinning among fields: Jung, Frye, Levi-Strauss, and feminist archetypal theory', in R.P. Sugg (ed.), Jungian literary criticism, pp. 153-166, Northwestern University Press, Evanston.

Schmitz, B., 2010, 'Holofernes' Canopy in the Septuagint', in K.R. Brine, E. Ciletti \& H Lähnemann (eds.), The sword of Judith: Judith studies across the disciplines, pp. 71-80, Open Book Publishers, Cambridge.

Stocker, M., 1998, Judith: Sexual warrior: Women and power in western culture, Yale University Press, New Haven/London.

Tait, P., 2010, 'The Kore: My experiences with the maiden archetype', Psychological Perspectives 53(2), 175-188. http://dx.doi.org/10.1080/00332921003780679

Taylor, J.G., 1982, 'The Song of Deborah and two Canaanite goddesses', Journal for the Study of the Old Testament 23, 99-108. http://dx.doi. org/10.1177/030908928200702306

Van der Toorn, K., 1992, 'Anat-Yahu, some other deities, and the Jews of Elephantine', Numen 39(1), 80-101. http://dx.doi.org/10.1163/156852792X00177

Van der Toorn, K., 1998, 'Currents in the study of Israelite religion', Currents in Research 6, 13-23.

Von Franz, M-L., 1964, 'The process of individuation', in C.G. Jung \& M-L. von Franz (eds.), Man and his symbols, pp. 158-229, Aldus Books, London. 